\title{
A cow-calf vs yearling substitution ratio for shortgrass steppe
}

L. FORERO, L.R. RITTENHOUSE, AND J.E. MITCHELL

\section{Abstract}

Managers often deal with the problem of herd replacement of one animal class by another. A preliminary study suggested that steers could be substituted for cow-calf pairs on shortgrass steppe on a weight:weight basis. This ratio was tested on 2 pairs of pastures, one dominated by native shortgrass steppe and the other by a seeded stand of sideoats grama (Bouteloua curtipendula (Michx.)Torr.). The pasture sizes were set so the cow-calf pastures were 1.8 times larger than the steer pastures to allow equal herd sizes for the $\mathbf{2}$ classes of animals. Adequacy of stocking was determined by equalizing utilization. The actual stocking ratios of 1.79 steers to 1 cow-calf pair on the native pastures and 1.78 steers to 1 cow-calf pair on the seeded pastures resulted in no significant differences in utilization or standing crop of remaining forage after the grazing season ended. Season-long, the $90 \%$ confidence bounds of the steer-weight:pair-weight ratio was $0.981-1.035$ and 0.968 0.985 for native and seeded pastures, respectively. This ratio provides an acceptable initial stocking rate guide for those wishing to change from cow-calf to steer operations, or vice versa, on the shortgrass steppe.

Key Words: shortgrass steppe, forage allocation, substitution ratio, animal unit equivalent

Western cow-calf ranchers are considering alternative enterprises with 1 possibility being replacement of cow-calf pairs by yearling steers. Advantages of a yearling enterprise include elimination of need to maintain the cow all winter, lower labor inputs, and a shorter time period for carrying of production loans by an operator. A yearling operation in conjunction with cow-calf pairs would increase the economic flexibility of a ranch by providing for the purchase or retention of yearling cattle during favorable years and their liquidation during less favorable ones.

When converting from a cow-calf operation to one involving yearlings, a substitution ratio must be chosen that allows for proper range use by the new class of livestock. The objective of this study was to establish such a ratio for the shortgrass steppe. The substitution ratio could be valuable in forage allocation aspects of ranch planning and decision-making.

Traditionally, substitution ratios have been calculated between species rather than classes of livestock. This study is a special case of the common use problem in that classes of livestock are being substituted rather than species.

It can be assumed that subtle differences in behavior do exist between yearling steers and cow-calf pairs in dietary selection, grazing patterns, and forage consumption. Behavior of cattle, which can be confounded with demand, is dependent upon pasture size, location of water, topography, spatial distribution of nutrients, social interactions, and a number of other factors (Roath and Krueger 1982, Senft, Rittenhouse and Woodmansee 1985). Scarnecchia and Kothmann (1982) recognized 4 variables in

\footnotetext{
Authors are farm advisor, Livestock and Land Use, University of California Cooperative Extension, Hayward 92139; professor, Department Range Science, Colorado State University, Fort Collins 80523; and range scientist, Rocky Mountain Forest and Range Experiment Station, Fort Collins 80526. At the time of the research, the senior author was research assistant, Range Science Department, Colorado State University. Authors wish to thank Derrell Peel for assistance in data collection and analysis.

Research was funded in part by the Colorado State University Agricultural Experiment Station, Project 15076!.

Manuscript accepted 27 December 1988.
}

animal-pasture relationships; i.e., pasture area, forage dry matter, duration of grazing, and animal demand. Only 1 major factor, animal demand, is considered in this study by holding the others reasonably constant.

The proper substitution ratio for supplanting cow-calf pairs with steers on shortgrass steppe must be verified by evaluating forage consumption by the 2 classes. Under field conditions, there are 2 approaches to carrying out such an evaluation: (1) estimating consumption using indirect in vivo methods (Van Dyne 1969), or (2) estimating utilization of forage produced during the grazing season (Cook and Stubbendieck 1986). Although the latter approach is not suited for intensive diet studies, it is adequate to compare overall consumption rates of livestock herds.

\section{Study Area}

The study was conducted at the Southeastern Colorado Research Center (SECRC) $\left(37^{\circ} 23^{\prime} \mathrm{N}\right.$ latitude and $102^{\circ} 44^{\prime} \mathrm{W}$ longitude) 11 km west of Springfield, Colorado. The Center is situated on the Comanche National Grasslands, administrated by U.S. Forest Service. Elevation is $1,400 \mathrm{~m}$ and topography is flat to slightly rolling. Climate of the study is typical of shortgrass steppe with hot summers, irregular precipitation events, and windy conditions during the growing season. Average annual precipitation recorded at SECRC from 1957 to 1985 was $385 \mathrm{~mm}$ (Peel 1986). In 1985 and 1986, annual precipitation was 352 and $429 \mathrm{~mm}$, respectively, with about two-thirds occurring between 1 May and 30 September.

Vegetation in native pastures was primarily warm-season species (Forero 1987). Ninety-two percent of the vegetation, by weight, consisted of about equal proportions of blue grama (Bouteloua gracilis (H.B.K.)Lag.) and buffalo grass (Buchloe dactyloides (Nutt.)Engelm.) with the remaining $8 \%$ consisting of sand dropseed (Sporobolus cryptandrus (Torr.)Gray), western wheatgrass (Agropyron smithii Rydb.), and red three-awn (Aristida longisita Steud.). Six-weeks fescue (Vulpia octoflora (Walter)Rydb.) was abundant early in 1985 . Seeded study pastures were planted to sideoats grama (Bouteloua curtipendula) about $\mathbf{4 0}$ years ago. About $38 \%$ of the vegetation was sideoats grama. The area also supported buffalo grass (16\%), palatable forbs (12\%), red threeawn (9\%), sand dropseed (9\%), bottlebrush squirreltail (Sitanion hystrix (Nutt.)J.G. Smith) (8\%), and some western wheatgrass, blue grama, sand dropseed, and other miscellaneous forbs and grasses.

\section{Methods}

Pilot Study (Estimation of Substitution Ratio)

A pilot study was conducted in 1985 on native and seeded pastures at the SECRC. Our objective was to ascertain an initial estimate of a cow-calf pair to yearling steer substitution ratio. Seeded areas consisted of two 130-ha pastures. Average stocking rate (145 days) was 0.242 steers or 0.132 cow-calf pairs per ha (Table 1). Native pastures totaled 65 and 93 ha. Average stocking rate for the same period was 0.241 steers or 0.134 cow-calf pairs per ha. The major criterion used to establish stocking rates was total animal weight.

Stocking rates assumed equal forage productivity in paired pas- 
tures. We further assumed additional requirements for maintenance and lactation in cows would be about the same fraction of body weight as additional requirements for growth in yearlings. Standing crop was monitored monthly throughout the grazing season. The objective was to end the grazing season with equal residual forage in paired pastures. Trials began on 1 June 1985 and ended on 24 October 1985.

Grazing pressure was equalized between opposing pastures by adjusting cattle numbers, thus changing the cow-calf:steer ratio. Decisions regarding the additional or removal of animals were made based upon 2 criteria: (1) comparison of standing crop, and (2) individual animal performances. Cow-calf pair to steer weight ratios were calculated for each sampling period and for the season (Table 1). Means reflected the average cow-calf to steer weight ratio for the season.

Procedures for the second part of the study were dependent on results from the pilot study. Analysis of the preliminary data indicated that a steer to cow-calf replacement ratio of $1: 1.8$ would result in equal utilization (or 1:1 on a weight:weight basis). Therefore, this substitution ratio was subsequently tested.

\section{Test of Ratio}

The same pasture types were used in 1986. The hypothesis was tested by adjusting the pasture sizes to equalize the number of cow-calf pairs and steers to achieve a 1:1.8 ratio (steers:pairs) of available forage per animal. Stocking rates were set at the start of the grazing season, 1 June, and remained constant until its end, 20 October. If the hypothesis was correct, grazing pressure within the sets of paired pastures would remain equal and total steer weight per ha would equal the total weight of cows and calves per ha over the grazing season.

Native pastures A (61 ha) and B (109 ha) were stocked with 13 yearling steers and 13 cow-calf pairs, respectively. The seeded pastures C (68 ha) and D (121 ha) were stocked with 15 steers and 15 cow-calf pairs, respectively. Vegetation and topography were essentially the same between paired pastures.

Grazing pressure was monitored across season by estimating the palatable standing crop of forage every 28 days. Given the assumption of equal forage production and ratios of utilization, then residual standing crop would also remain equal.

Estimates of standing crop were made using a double sampling approach (Wilm et al. 1944). Based on initial observations, a ratio of 5 plots estimated by eye per each plot clipped was used to minimize total variance (Cochran 1963). Plot size differed for the 2 study sites, with $0.25 \mathrm{~m}^{2}$ plots used on native pastures and $0.5 \mathrm{~m}^{2}$ plots on seeded pastures. Transects were placed at random intervals across the long axis of the pastures. Five to 6 plots (estimated plus clipped) were read along each of 8 to 10 transects per pasture. Both transects and plots were randomly allocated in each sampling period. Plot location was weighted by soil type. Sample size was sufficient to estimate mean standing crop (total) within $10 \%$, with $90 \%$ reliability.

Vegetation biomass, estimated by species, included only current year's growth measured from ground level. Unpalatable vegetation, such as red three-awn, bottlebrush squirreltail, and various forbs, was subtracted from total vegetation to give an estimate of total palatable biomass. Samples were oven-dried at $55^{\circ} \mathrm{C}$ for 48 hours prior to weighing.

Cattle used in the experiment consisted of Brahman crossed steers and Angus-Hereford crossed cows with $1 / 2$ Brahman calves. Animals were weighed at initiation of the experiment and every 28 days thereafter until the end of the grazing season. Animals were gathered the evening prior to the 28th day and allowed 12 to 16 hours for shrink (no food or water) before weighing.

A $t$-test was used to compare the standing crop means between the sets of paired pastures. Pastures were deemed similar if no
Table 1. Season-long cattle statistics from the preliminary study at the Southeast Colorado Research Center, 1985.

\begin{tabular}{|c|c|c|}
\hline \multirow[b]{2}{*}{ Class or ratio } & \multicolumn{2}{|c|}{ Vegetation type } \\
\hline & Native $^{\mathbf{a}}$ & Seeded $^{\mathrm{b}}$ \\
\hline $\begin{array}{l}\text { Average stocking rate }{ }^{c} \text {, steers-days / ha } \\
\text { Average stocking rate, pair-days/ha } \\
\text { Average steer weight, } \mathrm{kg} \\
\text { Average cow weight, } \mathrm{kg} \\
\text { Average calf weight, } \mathrm{kg} \\
\text { Average pair weight, } \mathrm{kg}\end{array}$ & $\begin{array}{r}34.9 \\
19.5 \\
316 \\
398 \\
166 \\
564\end{array}$ & $\begin{array}{r}35.1 \\
19.2 \\
317 \\
409 \\
152 \\
562\end{array}$ \\
\hline $\begin{array}{l}\text { Average } \mathrm{kg} \text {-days } / \mathbf{k g} \text {, steers } \\
\text { Average } \mathbf{k g} \text {-days/ha, pairs }\end{array}$ & $\begin{array}{l}11028 \\
10998\end{array}$ & $\begin{array}{l}11127 \\
10790\end{array}$ \\
\hline $\begin{array}{l}\text { Ratio steers-days/ha:pair-days/ha } \\
\text { Ratio steer kg-days/ha:pair kg-days/ha }\end{array}$ & $\begin{array}{l}1.79 \\
1.00\end{array}$ & $\begin{array}{l}1.83 \\
1.03\end{array}$ \\
\hline
\end{tabular}

The steer pasture and cow-calf pastures were 65 and 93 ha, respectively.

${ }^{b}$ Both the steer and cow-calf pastures were 130 ha

'The grazing season was 145 days

significant difference was noted at $P$ greater than or equal to 0.10 . A $t$-test was also used to compare steer weight per ha to cow-calf pair weight per ha throughout the season. The $90 \%$ confidence interval of the ratio was calculated according to Schaeffer et al. (1986). Variance was estimated from variation among ratios as the season progressed. Population size (N of Schaeffer et al. [1986]) was 141 days (grazing season); sample size (n) was 5 (sampling periods).

\section{Results and Discussion}

Mean weight of steers and cow-calf pairs per ha was similar $(P>.10)$ for both native and seeded pastures (Table 2). The ratios of steers to cow-calf pairs were consistent over the entire grazing season. The bounds of the $90 \%$ confidence interval for cow-calf pairs to steers ratios were 0.981 to 1.035 and .968 to 0.985 for the native and seeded pastures, respectively. That the $90 \%$ confidence interval for the seeded pastures failed to include the value 1 is of little practical consequence, because weights of steers and cow-calf pairs per ha were not significantly different.

Forage biomass in either the native or seeded pastures was not different $(P>.10)$ between steers and pairs at any time during the 1986 grazing season (Table 3 ).

This work indicates a weight:weight substitution ratio is applicable on shortgrass steppe. Weight of steers per area can be substituted for a similar weight of cow-calf pairs during a growing season. Many interacting factors may affect the value of this ratio, including animal type, weight, production, and environmental

Table 2. Animal response on native and seeded pastures \pm one standard error at the Southeast Colorado Research Center, 1986.

\begin{tabular}{|c|c|c|}
\hline \multirow[b]{2}{*}{ Class or ratio } & \multicolumn{2}{|c|}{ Vegetation type } \\
\hline & Native & Seeded $^{b}$ \\
\hline $\begin{array}{l}\text { Steers/pasture } \\
\text { Pairs/pasture } \\
\text { Average steer weight, } \mathbf{k g} \\
\text { Average cow weight, } \mathbf{k g} \\
\text { Average calf weight, } \mathbf{k g} \\
\text { Average pair weight, } \mathrm{kg}\end{array}$ & $\begin{array}{c}13 \\
13 \\
35 \pm 14 \\
431 \pm 12 \\
195 \pm 13 \\
626 \pm 20\end{array}$ & $\begin{array}{c}15 \\
15 \\
345 \pm 11 \\
431 \pm 10 \\
201 \pm 13 \\
632 \pm 19\end{array}$ \\
\hline $\begin{array}{l}\text { Steer days per hac } \\
\text { Pair days per ha }\end{array}$ & $\begin{array}{l}30 \\
17\end{array}$ & $\begin{array}{l}31 \\
18\end{array}$ \\
\hline $\begin{array}{l}\text { Average } K_{g} / \text { ha, steers } \\
\text { Average } K_{g} / \text { ha, pairs }\end{array}$ & $\begin{array}{l}75.1 \pm 2.9 \\
74.5 \pm 2.5\end{array}$ & $\begin{array}{l}76.5 \pm 2.4 \\
78.3 \pm 2.3\end{array}$ \\
\hline $\begin{array}{l}\text { Ratio steers-days/ha:pair-days/ha } \\
\text { Ratio steer kg-days/ha:pair kg-days/ha }\end{array}$ & $\begin{array}{c}1.79 \\
1.008 \pm .027\end{array}$ & $\begin{array}{l}1.78 \\
.976 \pm .008\end{array}$ \\
\hline
\end{tabular}

The steer pasture and cow-calf pastures were 61 and 109 ha, respectively. ${ }^{b}$ Steer and cow-calf pastures were 68 and 121 ha, respectively.

The grazing season was 142 days. 
Table 3. Residual standing crop (kg/ha) of palatable, herbaceous dry matter plus or minus the $80 \%$ confidence interval on native and seeded rangeland, 1986.

\begin{tabular}{lccccc}
\hline & \multicolumn{5}{c}{ Month } \\
\cline { 2 - 6 } Class & June & July & Aug. & Sep. & Oct. \\
\hline & & & Native & & \\
Steers & $613 \pm 36$ & $394 \pm 28$ & $807 \pm 56$ & $908 \pm 43$ & $840 \pm 36$ \\
Pairs & $539 \pm 43$ & $398 \pm 15$ & $719 \pm 60$ & $921 \pm 42$ & $839 \pm 35$ \\
& & & Seeded & & \\
Steers & $570 \pm 84$ & $315 \pm 34$ & $716 \pm 61$ & $639 \pm 49$ & $656 \pm 74$ \\
Pairs & $437 \pm 43$ & $344 \pm 31$ & $757 \pm 65$ & $698 \pm 65$ & $632 \pm 70$ \\
\hline
\end{tabular}

aspects. The ratio should be applied with caution if animals of extreme type are replaced by animals of opposite extremes. However, this study does provide baseline data with typical animals used in yearling/pair substitutions on the shortgrass steppe.

Additional work is needed to test sensitivity of the substitution ratio in environments where behavior and distribution of steers and cow-calf pairs may differ substantially.

\section{Literature Cited}

Cochran, W.G. 1963. Sampling techniques. 2nd ed. John Wiley and Sons, New York. 413 p.

Cook, C.W., and J. Stubbendieck. 1986. Range research: basic problems and techniques. Society for Range Management, Denver, Colo.

Forero, L. 1987. The determination of a steer:cow-calf substitution ratio at the southeastern Colorado Research Center. A M.S. Thesis. Colorado State University. Ft. Collins.

Peel, D.A. 1986. Climatological observations at the Southeastern Colorado Research Center, 1957-1985. Colorado State Univ., Agr. Exp. Sta., SE Colo. Res. Center Tech. Rep. TR86-6. Colorado State University, Ft. Collins.

Roath, L.R., and W. Krueger. 1982. Cattle grazing and behavior on a forested range. J. Range Manage. 35:332-338.

Scarnecehia, D.L., and M.M. Kothmann. 1982. A dynamic approach to grazing management terminology. J. Range Manage. 35:262-264.

Scheaffer, R.L., W. Mendenhall, and L. Ott. 1986. Elementary survey sampling. 3rd ed. Duxbury Press, Boston. p. 128-130.

Senft, R.L., L.R. Rittenhouse, and R.G. Woodmansee. 1985. Factors influencing patterns of grazing behavior on shortgrass steppe. J. Range Manage. 38:82-87.

Van Dyne, G.M. 1969. Measuring quantity and quality of the diet of large herbivores, p. 5-94. In: F.B. Golley and H.K. Buechner (ed.). A practical guide to the study of the productivity of large herbivores. Blackwell Scientific Publ., Oxford, Great Britain.

Wilm, H.G., D.F. Costello, and G.E. Klippe. 1944. Estimating forage yield by the double sampling method. J. Amer. Soc. Agron. 36:194-203.

\section{Associate Editor Nominations}

Replacements will be required for associate editors retiring from the Editorial Board in February, 1990. We are seeking nominees with expertise in plant physiology and grazing management, preferably with a background in measurement, modeling, or economics. Associate editors serve for 2 years with an optional second term. To nominate a candidate for this important and demanding position, ascertain that the individual is available and willing to serve and then send a letter of nomination to the editor describing the nominee's qualifications. The candidate will be asked to submit a list of publications and an account of experience in reviewing manuscripts. Send nominations to Patricia G. Smith, Editor, Journal of Range Management, 1839 York Street, Denver, CO 80206 by September 15, 1989. 